\title{
Non-Endoscopic Parameters for Predicton of Esophageal Varices
}

\author{
Rahul Pathak*, Roshan Jha, Prem khadga, Shashi sharma \\ Department of Gastroenterology, IOM \\ Kathmandu, Nepal
}

\section{DOI Name}

http://dx.doi.org/10.3126/jaim.v6i2.18537

\section{Keywords}

Non-endoscopic parameter; esophageal varices; platelet count/spleen diameter ratio; APRI

\section{Citation}

Rahul Pathak, Roshan Jha, Prem Khadga, Shashi sharma. Non-Endoscopic Parameters for Predicton of Esophageal Varices. Journal of Advances in Internal Medicine 2017;06(02):21-26.

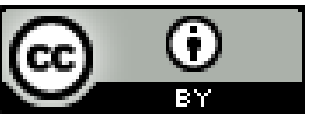

This work is licensed under a Creative Commons Attribution 3.0 Unported License.

\begin{abstract}
Introduction: Non invasive assessment of esophageal varices may improve the management and lower the medical and financial burden related to the screening. In this study, Our aim was to validate the prediction of varices using platelet count/spleen diameter ratio and Alanine transaminase/platelet ratio index (APRI).
\end{abstract}

Methods: Fifty patients with newly diagnosed and treatment naive cirrhosis underwent screening endoscopy along with hematological and ultrsonographic studies. Platelet count/spleen diameter ratio and APRI index were assessed and their diagnostic accuracy calculated. Based on previous studies, a cutoff of 909 was applied for platelet count/spleen diameter ratio and cutoff of $>1.3$ for APRI. The diagnostic accuracy of both the indices were further evaluated for severity and size of varices.

Results: Prevalence of varices was $36 \%$ out of which $24 \%$ were large varices. Platelet count/spleen size diameter, portal vein diameter and APRI index had significant association for prediction of presence of varices and strongly correlated with size of varices. Platelet count/spleen size diameter of 909 had diagnostic accuracy of $80.5 \%$ for prediction of varices with diagnostic accuracy being 95.8 for predicting large varices. APRI index of more than 1.3 had accuracy of $75 \%$ for predicting varices and $87.5 \%$ for accurately predicting them as large varices.

Conclusions: In a resource limited country like ours, where access to specialized and tertiary care hospitals and availability of endoscopy facilities in rural areas is an issue, these non invasive parameters platelet count/spleen diameter and APRI can be taken as a safe and reliable predictor for esophageal varices.

\section{INTRODUCTION}

Cirrhosis is the end stage for chronic liver disease and results in portal hypertension. Portal hypertension is associated with hyper dynamic circulation resulting in increased gradient and redirection of blood to areas with low venous pressure and finally forms esophageal, gastric, rectal varices. Gastroesophageal varices are the most relevant porto-systemic collaterals because their rupture results in variceal hemorrhage, the most common and lethal complication of cirrhosis. Esophageal varices are dilated sub-mucosal veins mostly in the lower third of the esophagus. Esophageal varices are present at diagnosis in approximately $50 \%$ of cirrhotic patients, being more common in Child-Pugh class C patients compared to

\footnotetext{
* Corresponding author

Dr. Rahul Pathak

Department of Gastroenterology

IOM, Kathmandu, Nepal

Email:pathak.drrahul@googlemail.com
} 
Child-Pugh class A patients (85\% versus $40 \%) .{ }^{1}$ The rate of development of new varices and increase in grades of varices is $8 \%$ per year; the former is largely predicted by a hepatic venous pressure gradient (HVPG) exceeding $10 \mathrm{~mm} \mathrm{Hg.}{ }^{2}$ De novo formation of varices occurs at a rate of $5 \%$ per year, with a higher incidence in patients continuing to consume alcohol or with worsening liver function. ${ }^{3}$ Once varices form, they enlarge from small to large at a rate of $5-12 \%$ per year and bleed at a rate of $5-15 \%$ per year. ${ }^{3}$ Patients with small varices develop large varices at the rate of $8 \%$ per year. Early diagnosis of varices before the first bleed is essential as studies of primary prophylaxis clearly show that the risk of variceal hemorrhage can be reduced by $50 \%$ to about $15 \%$ for large esophageal varices. ${ }^{4}$ Upper $\mathrm{Gl}$ endoscopy remains the gold standard for screening, but this test has its own limitations. It is an invasive procedure with significant cost and burden to the patients and endoscopy units. It necessitates patients having repeated unpleasant procedures even when up to $50 \%$ may still not have developed esophageal varices 10 years after the initial diagnosis. ${ }^{5}$ There is, therefore, considerable interest in developing models to predict the presence of high-risk varices by non-endoscopic methods. It may be more cost effective to screen these patients routinely at risk for presence of varices. If patients at low or high risk of having esophageal varices (EV) could be identified from easily obtainable clinical variables, a more affordable approach for screening would be possible. It would be very much helpful in a country like Nepal where availability and affordability of endoscopy is a thriving issue. Certain biochemical, clinical and ultrasonography parameters alone and in combination are found to have predictive value for assessing the presence of varices. ${ }^{6}$

\section{AIMS AND OBJECTIVES}

To identify the relationship and diagnostic accuracy and predictive value of non-endoscopic parameters like platelet count, spleen size, portal vein diameter and platelet count / splenic ratio, Aspartate aminotransferase/ platelet count ratio index (APRI) for the presence of esophageal varices. Also to determine the correlation between these parameters and size of varices along with the state of liver disease.

\section{Risk factors for variceal bleeding}

Variceal hemorrhage occurs at a yearly rate of $5 \%-15 \%$, and the most important predictor of hemorrhage is the size of varices, with the highest risk of first hemorrhage (15\% per year) occurring in patients with large varices. Other predictors of hemorrhage are decompensated cirrhosis (Child B/C) and the endoscopic presence of red wale marks and cherry red spots. Their presence correlates with the severity of liver disease while only $40 \%$ of Child A patients have varices, they are present in $85 \%$ of Child $\mathrm{C}$ patients. ${ }^{7}$ Patients without varices develop them at a rate of $8 \%$ per year and the strongest predictor for development of varices in those with cirrhosis who have no varices at the time of initial endoscopic screening is an HVPG $>10 \mathrm{mmHg}$. Patients with tense ascites are also at increased risk for bleeding from varices. Although bleeding from esophageal varices ceases spontaneously in up to $40 \%$ of patients, and despite improvements in therapy over the last decade, it is associated with a mortality of at least $20 \%$ at 6 weeks. ${ }^{8,9}$ Intra abdominal pressure clearly influences several hemodynamic variables in portal hypertension, but there is no concluding evidence that tense ascites increases the risk of variceal bleeding. ${ }^{10}$

Before the widespread use of current therapies for acute variceal hemorrhage, the mortality rate of a single variceal hemorrhage was 30 percent, and only one-third of patients survived for one year. ${ }^{11,12}$ Although survival has improved with modern techniques for controlling variceal hemorrhage, mortality rates remain high.

In a study by Carbonell et al., who showed that between 1980-2000, the in hospital mortality from variceal bleeding decreased from $42.6 \%$ to $14.5 \%$ and was associated with decreased re-bleeding.13Although mortality from a bleeding episode has decreased with improved endoscopic and radiological techniques together with new pharmacologic therapies, 20 - 30\% mortality means that bleeding from esophageal varices remains of significant clinical importance. ${ }^{14}$ Early diagnosis of varices before the first bleed is essential as studies of primary prophylaxis clearly show that the risk of variceal hemorrhage can be reduced by $50 \%$ to about $15 \%$ for large esophageal varices. ${ }^{15}$

\section{Non-endoscopic predictors:}

Current guidelines recommend that all cirrhotic patients should undergo screening endoscopy at diagnosis to identify patients with varices at high risk of bleeding who will benefit from primary prophylaxis. This approach places a heavy burden upon endoscopy units and the repeated testing over time may have a detrimental effect on patient compliance. Noninvasive identification of patients at highest risk for esophageal varices would limit investigation to those most likely to benefit. Several studies have examined the usefulness of different clinical and laboratory parameters as predictors of the presence or size of esophageal varices. 


\section{MATERIALS AND METHODS}

This cross-sectional analytical study was carried out at the Department of Internal Medicine, Tribhuvan University Teaching Hospital, Maharajgunj, Kathmandu, Nepal. Targeted sample sizes of 50 cirrhotic patients admitted to the hospital during the period from March 2012 to May 2014 were studied. Written informed consent was taken from each patient or their relatives prior to enrollment in study.

\section{METHODS}

All patients included in the study were evaluated for clinical, hematological, biochemical and ultra-sonographic parameters. Uniformity was maintained by repeating scans by the same radiologist to avoid inter observer variation. All patients underwent UGI endoscopy to evaluate for the presence and degree of esophageal varices using an Olympus video Endoscope GIF type $V_{2}$.UGI endoscopies were carried out mostly by the single gastroenterologist during the study period to avoid inter-observer disagreement. The degree of esophageal varices was classified according to Paquet Grading system of varices. ${ }^{42}$ and further classified into small and large varices based on AASLD and Baveno IV recommendations. ${ }^{6,43}$

\section{Etiology of Cirrhosis of liver}

Alcoholic liver disease was the most common cause of cirrhosis. It comprised of 43 patients (86\%). Chronic viral hepatitis B accounted for 5 cases (10\%) and Hepatitis C for 1 case (2\%). 1 case (2\%) had NASH as its cause for cirrhosis.

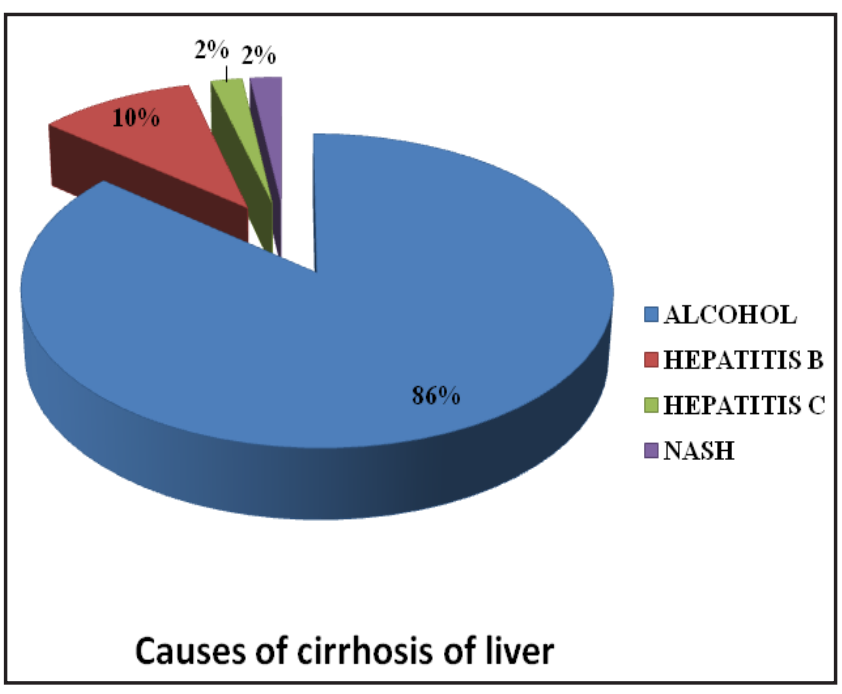

FIG 1: Etiological cause of Cirrhosis of Liver

Table 1: Clinical, biochemical and ultrasonography parameters: comparison between patients with and without esophageal varices.

\begin{tabular}{|c|c|c|c|}
\hline Variables & $\begin{array}{l}\text { Patients with } \\
\text { varices } \\
(n=36)\end{array}$ & $\begin{array}{c}\text { Patients } \\
\text { without varices } \\
(n=14)\end{array}$ & $\begin{array}{c}P \\
\text { value }\end{array}$ \\
\hline Age (years) & $48.47 \pm 9.6$ & $46.79 \pm 10$ & 0.585 \\
\hline $\operatorname{Sex}(M / F)$ & $\begin{array}{l}26(72.2 \%) / \\
10(27.8 \%)\end{array}$ & $\begin{array}{l}12(85.7 \%) / 2 \\
(14.3 \%)\end{array}$ & 0.468 \\
\hline Ascites & 34 (94.4\%) & $11(5.6 \%)$ & 0.126 \\
\hline $\begin{array}{l}\text { Hepatic } \\
\text { encephalopathy }\end{array}$ & $8(22.2 \%)$ & $3(21 \%)$ & 0.114 \\
\hline Bilirubin $(\mu \mathrm{mol} / \mathrm{l})$ & $117.75 \pm 85$ & $154.21 \pm 136$ & 0.26 \\
\hline Albumin ( $\mathrm{g} / \mathrm{L}$ ) & $28.1 \pm 3.2$ & $28.2 \pm 3.4$ & 0.985 \\
\hline $\begin{array}{l}\text { Prothrombin } \\
\text { time(sec) }\end{array}$ & $23.56 \pm 7.6$ & $24 \pm 10$ & 0.869 \\
\hline $\begin{array}{l}\text { Platelet count (N/ } \\
\mathrm{mm}^{3} \text { ) }\end{array}$ & $\begin{array}{l}110777 \pm \\
38605\end{array}$ & $165571 \pm 47842$ & 0.0001 \\
\hline Spleen size ( $\mathrm{mm}$ ) & $128.28 \pm 11.3$ & $121.9 \pm 13.26$ & 0.096 \\
\hline $\begin{array}{l}\text { Portal vein size } \\
(\mathrm{mm})\end{array}$ & $13.1 \pm 0.78$ & $12.07 \pm 1.24$ & 0.0001 \\
\hline $\begin{array}{l}\text { Platelet/spleen } \\
\text { ratio }\left[\mathrm{N} / \mathrm{mm}^{3}\right) / \\
\mathrm{mm}]\end{array}$ & $\begin{array}{l}882.69 \pm \\
407.7\end{array}$ & $1383 \pm 464$ & 0.0001 \\
\hline $\begin{array}{l}\text { APRI }[(I U / L) / N / \\
\left.\mathrm{mm}^{3}\right]\end{array}$ & $1.54 \pm 0.61$ & $1.18 \pm 0.63$ & 0.071 \\
\hline
\end{tabular}

Data expressed as Mean $\pm S D$, statistical analysis by $\boldsymbol{x}^{2}$ and student $\mathbf{t}$ test.

The above table 1 shows that age and gender wise differences in cirrhotic population were not statistically significant for the presence of esophageal varices. Among the 50 cirrhotic patients studied, 36 patients (72\%) had endoscopic evidence of esophageal varices. Laboratory values of prothrombin time, serum albumin and bilirubin levels did not have significant differences among the groups with varices and without varices. Platelet count values among the cirrhotic with varices were significantly lower, $110777( \pm 38605)$ as compared to $165571( \pm 47842$ ) among those without varices with significant $p$ value. Size of spleen as measured by ultrasonography of abdomen showed that larger spleen size were associated with the presence of esophageal varices, 128.28 ( \pm 11.3 ) in group with varices as compared to 121.9 ( \pm 13.26$)$ in group without varices, however the association was statistically not significant. Moreover the platelet count and spleen diameter ratio had a significant association for presence of varices with mean value of 882.69 ( \pm 407.7$)$ in cirrhotic with varices as compared to 1383 ( \pm 464$)$ in cirrhotic without varices and the association was statistically significant.

Portal vein diameter with mean value of $13.1 \mathrm{~mm}$ was also 
associated with presence of esophageal varices as compared to mean value of $12.07 \mathrm{~mm}$ in those without varices with a significant $p$ value. APRI, aspartate aminotransferase to platelet ratio index showed mean value of 1.58 in cirrhotic with varices against 1.18 in those without varices, though the association was statistically not significant.

Association of platelet count/ spleen diameter ratio and esophageal varices

The ratio of platelet count and spleen diameter had strongest correlation among all the predictors studied. It had a highest correlation coefficient of 0.52 and 0.47 for the presence of varices and presence of large varices respectively. The platelet count/ spleen diameter ratio mean values were significantly lower in those with varices, mean value of 882.69 ( \pm 407.7 ) in cirrhotic with varices as compared to $1383( \pm 464)$ in cirrhotic without varices with a significant $p$ value. Similarly the ratio had a strong correlation with presence of large varices evidenced by values of $742.588 \pm 121$ for large varices as compared with $1162 \pm 607$ for small varices with a significant $p$ value $<0.05$.

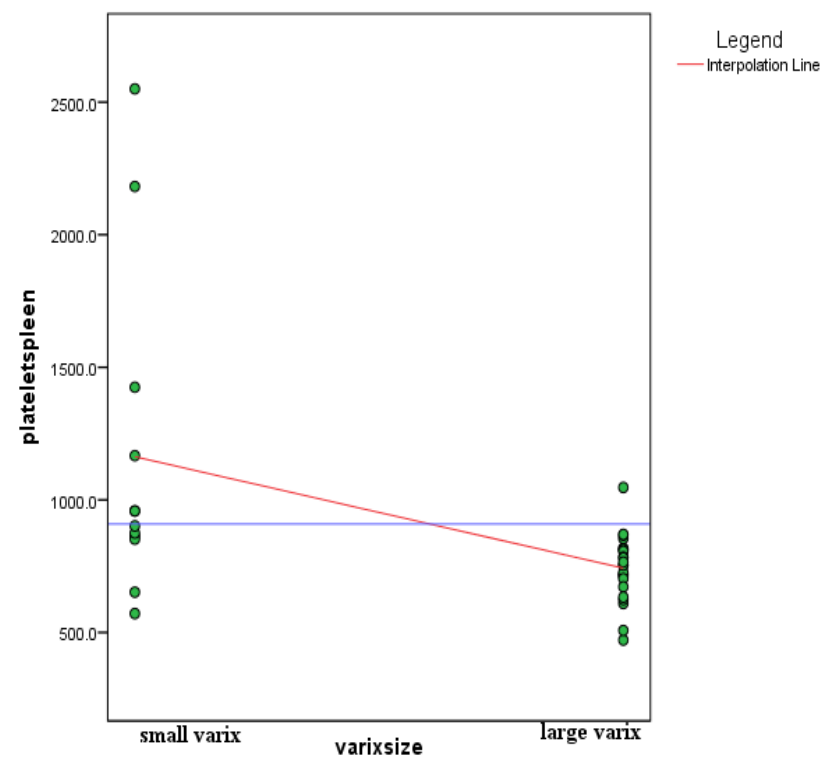

Figure 2: Scatter diagram showing association between platelet count/ spleen diameter ratio and size of varix.

Using the cut-off of platelet count/ spleen diameter ratio of 909 showed strong correlation and association for presence of varices as well as for further predicting large sized varices.

\section{Association of APRI and esophageal varices}

APRI values did show differences among the patients with varices compared to those without varices with mean value of 1.58 in cirrhotic with varices against 1.18 in those without varices, though the association was statistically not significant.
Same was the case for patients with large varices where APRI value of $1.65 \pm 0.58$ was present as compared to $1.34 \pm 0.66$ for patients with small varices and yet again the association was not significant statistically.



Figure 3: Scatter diagram and interpolation line showing association between APRI and size of varices.

Table 2: Non-endoscopic parameters and their correlation with presence of esophageal varices using the study cut-off values.

\begin{tabular}{|c|c|c|c|c|}
\hline Parameters & $\begin{array}{c}\text { With } \\
\text { varices } \\
\mathrm{n}=36\end{array}$ & $\begin{array}{l}\text { Without } \\
\text { varices } \\
n=14\end{array}$ & $P$ value & $\begin{array}{c}\text { cor- } \\
\text { relation } \\
\text { coeffi- } \\
\text { cient }\end{array}$ \\
\hline $\begin{array}{l}\text { Platelet count } \\
\text { (cutoff of } \\
<100000 / \mathrm{mm} 3 \text { ) }\end{array}$ & $\begin{array}{l}14 \\
(38.88 \%)\end{array}$ & $\begin{array}{l}2 \\
(14.2 \%)\end{array}$ & 0.175 & 0.23 \\
\hline $\begin{array}{l}\text { Spleen size } \\
\text { (cut-off of }> \\
130 \mathrm{~mm})\end{array}$ & $\begin{array}{l}17 \\
(47.2 \%)\end{array}$ & $\begin{array}{l}5 \\
(35.7 \%)\end{array}$ & 0.537 & 0.104 \\
\hline $\begin{array}{l}\text { Portal vein size } \\
\text { ( cut off of }>13 \\
\mathrm{~mm} \text { ) }\end{array}$ & $\begin{array}{l}22 \\
(61.11 \%)\end{array}$ & $\begin{array}{l}3 \\
(21.42 \%)\end{array}$ & 0.025 & 0.336 \\
\hline $\begin{array}{l}\text { Platelet count/ } \\
\text { spleen size } \\
\text { ratio } \\
\text { ( cut-off of } \\
<909 \text { ) }\end{array}$ & $\begin{array}{l}29 \\
(80.5 \%)\end{array}$ & $2(14 \%)$ & 0.0001 & 0.523 \\
\hline $\begin{array}{l}\text { APRI index } \\
(\text { cutoff }>1.3)\end{array}$ & $27(75 \%)$ & $\begin{array}{l}5 \\
(35.7 \%)\end{array}$ & 0.019 & 0.345 \\
\hline
\end{tabular}


Table 3: Non-endoscopic parameters and their correlation with size of esophageal varices using the study cut-off values.

\begin{tabular}{lcccc}
\hline \multicolumn{1}{c}{ Parameters } & $\begin{array}{c}\text { Small vari- } \\
\text { ces } \\
\mathbf{n = 1 2}\end{array}$ & $\begin{array}{c}\text { Large } \\
\text { varices } \\
\mathbf{n = 2 4}\end{array}$ & $\begin{array}{c}\text { P } \\
\text { value }\end{array}$ & $\begin{array}{c}\text { Correlation } \\
\text { coefficient }\end{array}$ \\
\hline $\begin{array}{l}\text { Platelet count } \\
\text { (cutoff of }<100000 / \\
\text { mm3) }\end{array}$ & $2(16.67 \%)$ & $12(50 \%)$ & 0.076 & 0.307 \\
$\begin{array}{l}\text { Spleen size } \\
\text { (cutoff of }>130 \mathrm{~mm} \text { ) }\end{array}$ & $3(21.4 \%)$ & $14(58.3 \%)$ & 0.083 & 0.3 \\
$\begin{array}{l}\text { Portal vein size } \\
\text { (cut off of }>13 \mathrm{~mm})\end{array}$ & $4(33.33 \%)$ & $18(75 \%)$ & $\mathbf{0 . 0 2 9}$ & 0.374 \\
$\begin{array}{l}\text { Platelet count/ } \\
\text { spleen size ratio } \\
\text { (cutoff of }<909)\end{array}$ & $6(50 \%)$ & $23(95.83 \%)$ & $\mathbf{0 . 0 0 3}$ & $\mathbf{0 . 4 7 9}$ \\
$\begin{array}{l}\text { APRI index } \\
\text { (cutoff }>1.3)\end{array}$ & $6(50 \%)$ & $21(87.5 \%)$ & $\mathbf{0 . 0 3 6}$ & 0.378 \\
\hline
\end{tabular}

Table 4: Diagnostic features of Non-endoscopic predictors for the presence of esophageal varices

\begin{tabular}{|c|c|c|c|c|c|c|c|}
\hline Predictors & $\begin{array}{l}\text { Sensi- } \\
\text { tivity }\end{array}$ & $\begin{array}{l}\text { Speci- } \\
\text { ficity }\end{array}$ & PPV & NPV & PLR & NLR & $\begin{array}{c}\text { Corre- } \\
\text { lation } \\
\text { coef- } \\
\text { ficient }\end{array}$ \\
\hline $\begin{array}{l}\text { Platelet count } \\
\text { (cutoff of } \\
<100000 \text { / } \\
\mathrm{mm} 3 \text { ) }\end{array}$ & $38.39 \%$ & $85.71 \%$ & $87.5 \%$ & $35.29 \%$ & 2.72 & 0.71 & 0.23 \\
\hline $\begin{array}{l}\text { Spleen size } \\
\text { (cutoff of } \\
>130 \mathrm{~mm} \text { ) }\end{array}$ & $47.22 \%$ & $64.29 \%$ & $77.27 \%$ & $32.14 \%$ & 1.32 & 0.82 & 0.104 \\
\hline $\begin{array}{l}\text { Portal vein } \\
\text { size } \\
\text { ( cut off of } \\
>13 \mathrm{~mm} \text { ) }\end{array}$ & $61.11 \%$ & $78.57 \%$ & $88 \%$ & $44 \%$ & 2.85 & 0.49 & 0.336 \\
\hline $\begin{array}{l}\text { Plateletcount/ } \\
\text { spleen size } \\
\text { ratio } \\
\text { (cutoff of } \\
<909 \text { ) }\end{array}$ & $80.56 \%$ & $85.71 \%$ & $93.55 \%$ & $63.16 \%$ & 5.64 & 0.23 & 0.523 \\
\hline $\begin{array}{l}\text { APRI index } \\
\text { (cutoff }>1.3 \text { ) }\end{array}$ & $75 \%$ & $64.35 \%$ & $84.38 \%$ & $50 \%$ & 2.1 & 0.39 & 0.345 \\
\hline
\end{tabular}

PPV- positive predictive value, NPV - negative predictive value, PLR- positive likelihood ratio, NLR- negative likelihood ratio
Table 5: Diagnostic features of Non-endoscopic predictors for the presence of large varices

\begin{tabular}{|c|c|c|c|c|c|c|c|}
\hline Predictors & $\begin{array}{l}\text { Sensi- } \\
\text { tivity }\end{array}$ & $\begin{array}{l}\text { Speci- } \\
\text { ficity }\end{array}$ & PPV & NPV & PLR & NLR & $\begin{array}{l}\text { Corre- } \\
\text { lation } \\
\text { coeff- } \\
\text { cient }\end{array}$ \\
\hline $\begin{array}{l}\text { Platelet count } \\
\text { (cutoff of } \\
<100000 \text { / } \\
\mathrm{mm} 3 \text { ) }\end{array}$ & $50 \%$ & $83.33 \%$ & $85.71 \%$ & $45.45 \%$ & 3 & 0.6 & 0.307 \\
\hline $\begin{array}{l}\text { Spleen size } \\
\text { (cutoff of }>130 \\
\mathrm{~mm} \text { ) }\end{array}$ & $58.3 \%$ & $75 \%$ & $82.35 \%$ & $47.3 \%$ & 2.33 & 0.56 & 0.3 \\
\hline $\begin{array}{l}\text { Portal vein size } \\
\text { ( cut off of }>13 \\
\mathrm{~mm} \text { ) }\end{array}$ & $75 \%$ & $66.67 \%$ & $81.82 \%$ & $57.14 \%$ & 2.25 & 0.38 & 0.374 \\
\hline $\begin{array}{l}\text { Plateletcount/ } \\
\text { spleen size } \\
\text { ratio } \\
\text { (cutoff of } \\
<909 \text { ) }\end{array}$ & $95.83 \%$ & $50 \%$ & $79.31 \%$ & $85.71 \%$ & 1.92 & 0.08 & 0.479 \\
\hline $\begin{array}{l}\text { APRI index } \\
\text { (cutoff }>1.3 \text { ) }\end{array}$ & $87.5 \%$ & $50 \%$ & $77.78 \%$ & $66.67 \%$ & 1.75 & 0.25 & 0.378 \\
\hline
\end{tabular}

PPV- positive predictive value, NPV - negative predictive value, PLR- positive likelihood ratio, NLR- negative likelihood ratio

\section{DISCUSSION}

Severe upper gastrointestinal bleeding as a complication of portal hypertension develops in about $30-40 \%$ of patients with cirrhosis. Due to the increasing prevalence of chronic liver diseases, variceal hemorrhage is associated with significant morbidity, mortality, and health care costs. Numerous studies have demonstrated the efficacy of pharmacotherapy for primary prevention of variceal bleeding in patients with highrisk varices indicating the importance of screening for the presence of esophageal varices.

Although this study had a small sample population, based on the inferred results, the use of Platelet count/Spleen diameter ratio and Portal vein size showed a good result and high yield in predicting esophageal varices and thereby presence of large varices in cirrhosis patients. The use of this strategy of non-endoscopic parameters would necessarily lower the cost of management of cirrhotic patients since no additional expense would be entailed with the use of ultrasonography and routine hematological and biochemical tests. As the yearly incidence of esophageal varices in patients with cirrhosis is approximately $5 \%$, it is felt that the use of non-invasive non endoscopic diagnostic modality would provide an affordable alternative to detection of esophageal varices. 


\section{REFERENCES.}

1. Pagliaro L, D’Amico G, Pasta L, Politi F, Vizzini G, Traina $M$, et al. Portal hypertension in cirrhosis: Natural history. In: Bosch J, Groszmann RJ, editors. Portal hypertension. Pathophysiology and Treatment. Oxford: Blackwell Scientific; 1994. pp. 72-92

2. Groszmann RJ, Garcia-Tsao G, Bosch J, Grace ND, Burroughs AK, Planas R, et al. Beta-blockers to prevent gastroesophageal varices in patients with cirrhosis. $\mathrm{N}$ Engl J Med. 2005;353:2254-61.

3. M. Merli, G. Nicolini, S. Angeloni et al., "Incidence and natural history of small esophageal varices in cirrhotic patients," Journal of Hepatology, vol. 38, no. 3, pp. 266272, 2003.

4. G. D’Amico, L. Pagliaro, J. Bosch, and D. Patch, "Pharmacological treatment of portal hypertension: an evidence-based approach," Seminars in Liver Disease, vol. 19, no. 4, pp. 475-505, 1999.

5. M. Merli, G. Nicolini, S. Angeloni et al., "Incidence and natural history of small esophageal varices in cirrhotic patients," Journal of Hepatology, vol. 38, no. 3, pp. 266272, 2003.

6. D'Amico G, Morabito A. Noninvasive markers of esophageal varices: another round, not the last. HEPATOLOGY 2004; 39:30-34.

7. Pagliaro L, D’Amico G, Pasta L, Politi F, Vizzini G, Traina $M$, et al. Portal hypertension in cirrhosis: Natural history. In: Bosch J, Groszmann RJ. Portal Hypertension. Pathophysiology and Treatment. Oxford, UK: Blackwell Scientific, 1994: 72-92.
8. D’Amico G, de Franchis R. Upper digestive bleeding in cirrhosis. Posttherapeutic outcome and prognostic indicators. HEPATOLOGY 2003;38:599-612.

9. Carbonell N, Pauwels A, Serfaty L, Fourdan O, Levy VG, Poupon R.Improved survival after variceal bleeding in patients with cirrhosis over the past two decades. HEPATOLOGY 2004;40:652-659.

10. Luca A, Cirera I, Gargia- Pagan JC, et al. Hemodynamic effects of acute changes in intra-abdominal pressure in patients with cirrhosis. Gastroeneterlogy : 222, 1993

11. Smith JL, Graham DY. Variceal hemorrhage: a critical evaluation of survival analysis. Gastroenterology 1982; 82:968.

12. Graham DY, Smith JL. The course of patients after variceal hemorrhage. Gastroenterology 1981; 80:800.

13. N. Carbonell, A. Pauwels, L. Serfaty, O. Fourdan, V. G. L'evy, and R. Poupon, "Improved survival after variceal bleeding in patients with cirrhosis over the past two decades," Hepatology, vol. 40, no. 3, pp. 652-659, 2004.

14. L. Pagliaro, G. D’Amico, L. Pasta et al., "Efficacy and efficiency of treatments in portal hypertension," in Proceedings of the 2 nd Baveno International Consensus Workshop on Definitions, Methodology and Therapeutic Strategies, R. de Franchis, Ed., Portal Hypertension II, pp. 159-179, Blackwell Science, Oxford, UK, 1996.

15. G. D’Amico, L. Pagliaro, J. Bosch, and D. Patch, "Pharmacological treatment of portal hypertension: an evidence-based approach," Seminars in Liver Disease, vol. 19, no. 4, pp. 475-505, 1999. 